\title{
Style in the "questione della lingua:" the case of Ascanio de' Mori
}

Studies of the "questione della lingua" tend to focus on the major participants in the debate, those who defined a position by publishing their views (Bembo, Castiglione, Machiavelli, and a host of others); or else they examine the works of major authors to determine how their use of language was affected by the ideas of the theorists (Ariosto's revisions of the Furioso, Tasso's problems with the Crusca). 'This article will present a relatively minor figure, previously overlooked in this context, and it will show the struggles of an average nonTuscan writer in the latter part of the 16th century to write in a language for which there was still no fixed standard. Try as he might to conform to Trecento Florentine conventions of spelling, morphology, and lexicon (and this was not easy - even in Florentine usage there were oscillations), ${ }^{2}$ he was very much aware that the main problem was one of style.

Ascanio de' Mori lived from 1533 to $1591 .^{3}$ Little is known about his early life: he grew up in Medole, half-way between Brescia and Mantova, apparently studied at Bologna, and then seems to have spent about 20 years as a soldier in the service of the Gonzagas and the Emperor Maximilian II, fighting the Turks. ${ }^{4}$ In his forties he turned to literature. If he is remembered at all today it is usually as a novelliere - in fact, he is usually mentioned as a typical example of how novellieri adapted to the new moral climate of the Counter-Reformation ${ }^{5}$ - but in his own day, the work which brought him renown was the Giuoco Piacevole. It was first published in 1575 and was successful enough for two more editions in 1580 and $1590 .^{6}$

The Giuoco Piacevole is the narrative account of a veglia during Carnival of 1566 in Brescia. The assembled ladies and gentlemen play a game, the alphabet game, in which the players are each assigned a different letter and they must tell a story of a trip they took to a city beginning with that letter, naming the inn and innkeeper and a garden they visited, an animal and bird they saw in the garden, a poem they heard, and so forth; each name as well as the poem must begin with this letter. ${ }^{7}$ Although the whole book of about a hundred pages is a transcription of this game, it makes more interesting reading than it might seem. There is enough variety in the eighteen accounts, and enough by-play between the participants, to reward the curious reader. ${ }^{8}$

My evidence of Ascanio de' Mori's linguistic ideas and their evolution comes from three sources: first his letters, secondly the Giuoco Piacevole itself-speeches about language that he puts in the mouths of various 
characters - and lastly his revisions of the Giuoco Piacevole. ${ }^{9}$ Each new edition was advertised as "migliorato dall'autore," and in fact virtually each page shows at least some change, however slight, from one edition to the next.

Near the beginning of the Giuoco Piacevole, the assembled guests have decided to play a game, but there is some hesitation about choosing one. The hostess ${ }^{10}$ wants everybody present to propose a game because that is how "i nostri maggiori" did it. Obviously "i nostri maggiori" include the courtiers at Urbino in Castiglione's Cortegiano: they chose a game by having everybody propose one. The Cavaliere Giulio Foresti responds (I am condensing the arguments) that they need not mind how their predecessors did things - that would be superstition; they should use their own judgment. In any case, they need not worry about following models because this game will not be written down; it will not see the morrow. It will not be read by "scrupolosi" who want "periodi alti \& pieni, colori, metafore, \& digressioni, dottrina, gravità, \& parole Toscane scelte, non pur ne' ragionamenti gravi, ma ne' leggieri, \& ne' burlevoli." "In other words, the reason they might want to follow a model if the game were to be written down is that there are some "scrupolosi" out there who want us to write in a polished style not only on serious matters (and he seems to admit that when writing on serious matters this is desirable), but also on lighter topics. I will return shortly to the specific aspects of style that he mentions here but first let us finish with the Cavaliere's speech. "Even so," he says, "even if it were written down, what is wrong with my Lombard tongue? God gave it to me, and I can express myself well in it." The hostess agrees: since this is only a game, what would it matter even if it were written down $?^{12}$

It is difficult to extract a clear position on the "questione della lingua" from this speech of the Cavaliere, but it appears to be that, when we are speaking among friends, we need not worry about language, but just speak naturally; when we are writing on serious matters, we should take great care with our language and style and try to follow the great models of the past. The problem is what to do when we are writing on lighter matters. The Cavaliere seems to think that only the over-scrupulous require that we should take such care in this case. Our every-day written language should be sufficient. This is the heart of the problem for Ascanio de' Mori: he usually writes on lighter subjects (games, novelle); just how closely need he conform to the Trecento Florentine model advocated by Bembo, used by Della Casa and others, and now supported by the Accademia della Crusca?

We can now return to the Cavaliere's list of stylistic features that the "scrupolosi" want in all works, not just serious ones: "periodi alti \& pieni; colori, metafore, \& digressioni; dottrina, gravità; \& parole toscane scelte." In 1589, in a letter to Gio. Giacomo Calandra, Ascanio is commenting on a volume of letters by "Sig. F.", a gentleman, that his friend had sent him. Although he lists at great length the author's many virtues, the overall im- 
pression is one of grudging praise. De' Mori in fact admits that his opinion is "punto appassionato" (Lettere 164); poor Mr. F. lacks a true gift. He did not spare himself, and he accomplished everything that one possibly could by dint of effort alone, but this is not enough for de' Mori. ${ }^{13}$ Nevertheless it is interesting to read the stylistic checklist against which Ascanio measures Mr. F.'s performance. If these features are not sufficient, they are at least desirable, one assumes. Many of the criteria are the same as those used by the "scrupolosi." Mr. F., for instance, has used "gran considerazione alle locuzioni, a' periodi, alle concatenazioni, alle digressioni, alle insinuazioni, alle interposizioni, e al resto di ciò, studiando di osservare le regole de' più valent'uomini, riducendo tutto sotto gli ordini loro." (164) All this refers to the style; then he goes on to examine the choice of words. The "scrupolosi" in the Cavaliere's speech wanted "parole toscane scelte;" Mr. F. has in general followed the best models and, if sometimes he has copied some less strict authors in the use of new words ("new" presumably meaning after the Trecento), he has chosen the words carefully according to their intrinsic qualities. They are sweet, sonorous, beautiful, elegant, intelligible and meaningful and, although they are new or foreign words, most people do not even realize this, and they will soon be completely naturalized. In other words, the words to be used must either be certified by good authority, or else be well and carefully chosen. $^{14}$

Does this mean that all words certified by good authority, that is, all words used by Florentine Trecento authors, are good? For an answer to this question we must look at another passage from the Giuoco Piacevole. When it comes Signor Tranquillo's turn to talk, he begins by explaining that, although he is a soldier, nonetheless he has not forgotten his Tuscan letters: he starts off in a self-consciously high style (and note that his first word is the first word of the first day of the Decameron): "Quantunque sia mai sempre suto mio principale oggetto, il gir sovente armeggiando, \& vagando hor quinci, hor quindi per valli ombrose \& per monti alpestri ..." He sustains this tone through two long sentences and then breaks into another much lower register, using such words as gnaffe, chenti, mone, babbi. Then he asks, "Non è questo un principio alto, \& degno dell"aspettatione c'havevate di me?" "Anzi dignissimo," someone responds, "Toscano nostro gentilissimo da Brescia," and they all laugh. Signor Tranquillo goes on: "none of you till now had used even one of these elegant words, and I used so many of them; and yet you all consider yourselves Boccacceschi! Money wasn't wasted on me when they taught me to toscaneggiare!"15

If we examine Signor Tranquillo's little speech, we see that both in the first more solemn part and in the last bizarre sentence, he uses a whole series of Boccaccian words and expressions that had by the 16 th century fallen out of general use, or that seemed too locally Florentine for national consumption, words such as suto as a past participle of essere, mai sempre, gire, quinci $e$ quindi, non ha guari, etiandio, testé, avegnadio che, sovente, unqua; and 
then gnaffe, chenti, imbolare, boce for voce, fedire, formose, melensi, monne, babbi, and many others. By assembling all these words together in a short speech, Signor Tranquillo seems to be poking fun at the Boccaccisti, those who, as the phrase went, "favellano per quinci e quindi." ${ }^{, 16}$ But does he speak for de' Mori himself? We must read on: the Count now intervenes saying: "Do not make fun of those words: after Boccaccio, also Bembo, Della Casa, Molza, Guidiccione and others worthy of our imitation, approved these words and used some of them, scattered like precious gems in their writings." One can confirm the truth of the Count's assertion by opening to any page of, for instance, Bembo's Prose or Della Casa's Galateo; where, as likely as not, one will find an etiandio, and possibly an avvegnadio che, testé, non ha guari, etc. ${ }^{17}$ Signor Tranquillo does not offer a rebuttal. He indicates instead that he had indeed hoped to provoke such a response from the learned Count. It is up to the Cavaliere, the same character who at the beginning of the game was the spokesman for the author's linguistic outlook, to draw conclusions; Signor Tranquillo, he says, merely wanted to point out that, although these are all good words, they must be used sparingly in the right place, not all together in a short space. ${ }^{18}$ We see then that even the lexical issue is reduced to a question of style: all duly-pedigreed words are potentially good, but they must be used with discretion.

How does one acquire this discretion? Presumably by reading the best authors and consulting with experts. It is well known, for instance, that Guarini submitted his Pastor fido to Leonardo Salviati, one of the founders of the Crusca, for stylistic revisions (see Battaglin 1964-65 and 1970). Ascanio de' Mori, in another letter of 1589 , regrets that he does not have the leisure to travel to Florence to attend the meetings of the Accademia della Crusca. ${ }^{19}$ No doubt he discussed questions of style with someone whose opinion he respected, perhaps even his friend Torquato Tasso, but Tasso must not have been his ultimate authority, as there are forms, that Tasso uses fairly consistently, that de' Mori ultimately rejects. ${ }^{20}$

One more point about Signor Tranquillo's introduction; his little speech is crammed with trecentismi. This is the only passage in the Giuoco Piacevole that meets all of the stylistic criteria of the "scrupolosi." The first two sentences are marked not only by the choice of words, "parole Toscane scelte," but also by Ciceronian periods, rhetorical ornamentation of various types, parenthetical insertions, and "dottrina" or erudition. Among the mythological references are obscure periphrases for Death ("l'edace germana di Morfeo") and Fame ("l'occhiuta dea").

To see how de' Mori's linguistic theories were translated into practice, we must look at the two revisions of the Giuoco Piacevole. We can leave aside the few substantive changes and insertions, and the spelling problems are predictable enough for a Northerner. ${ }^{21}$ More interesting are the stylistic changes. It is important to remember that each change involves a decision that the new word is in some way better. In many cases both words have the 
authority of Trecento authors.

Between the 1575 and 1580 editions, the most frequent and consistent changes involve pronouns. First of all, originally de' Mori had used esso, essa, essi (referring to people or things) in oblique cases (di essi, in esso); realizing that Tuscan grammar restricts their use to subject pronouns, he changes them to lui, lei, loro, quello, and quella. ${ }^{22}$ Then, as to the direct object pronoun $l o$, early Italian usage favored $i l$ after a vowel, and de' Mori revises his work to conform to this already out-of-date practice. "Che lo bramiamo" (1575 ed., 10v) becomes "che il bramiamo" (1580 ed., 14r); "subito lo porse" (1575 ed., 19v) becomes "subito il porse" (1580 ed., 22v); "perciò lo percoteva" (1575 ed., 31v) becomes "perciò il percoteva" (1580 ed., 34r), etc. Another very frequent pronoun change is the replacement of cui after a preposition with il quale / la quale, etc., and this not only in the rare cases where there might be ambiguity of antecedent. ${ }^{23}$ Lastly, the indefinite pronouns chi ...chi and the non-Boccaccian altri ... altri are changed to quale ... quale, as in "chi andava quà, \& chi là a provedersi d'albergo ... " (1575 ed., 9v), which becomes "quale andava quà, \& quale là " (1580 ed., $13 v)^{24}$

In the first revision de' Mori also changes all instances of anco to anche, not only in the prose, but also, in one case, in verse (1575 ed., 8r; 1580 ed., 12r). (Many of his contemporaries preferred anco in verse. ${ }^{25}$ For some reason he also changes most occurrences of the adverb tanto to cotanto. ${ }^{26}$

In both revisions, de' Mori favors abstract nouns with suffixes, rather than the shorter form that might also be used as a verb or adjective: comodo (1575 ed., 34v) / comodità (1580 ed., 36v), contento (1575 ed., 34v) / contentezza (1580 ed., 36v); and ten years later, priego (1580 ed., 6r) / preghiera (1590 ed., 6r), obligo (1580 ed., 8v and passim) / obligatione (1590 ed., 8v and passim), scongiuro (1580 ed., 6r) / scongiuratione (1590 ed., 6r), castigo (1580 ed., $21 \mathrm{v})$ / gastigamento (1590 ed., 21v). ${ }^{27}$ Some words which are seen as archaic disappear: pezza, referring to time, becomes spatio; ${ }^{28}$ the noun bisogna, which in the Trecento meant "affare, negozio, faccenda," and which de' Mori does originally use in that sense, is turned into bisogno. ${ }^{29}$ On the other hand, some words that do not have Trecento authority are eliminated: custode, for instance, ${ }^{30}$ or tartaruga (1580 ed., 42r), which becomes testuggine (1590 ed., $42 \mathrm{r})^{31}$

In the second revision the principal changes are the elimination of much of the apocope, probably scen as too Northern: pur becomes pure, condition, conditione, etc.; the correct use of gli as the plural article beforc $s$ impure, $a$ ' spettacoli (1580 ed., 49r) / agli spettacoli (1590 ed., 49r); ${ }^{32}$ the contraction of the future stem in verbs likc doireste, andrai; and above all, the almost total elimination of the construction venire plus past participle in favor of the passive with essere: venne posto (1580 ed., 47r) / fu posio (1590 ed., 47r), essendo venuta lodata (1580 ed., 40r) / essendo stata lodata (1590 ed., 40r). I counted at least 33 examples of this change. Similarly, impersonal 
constructions such as mi vennero composte (1580 ed., 48v) are converted into active forms: le composi (1590 ed., $48 \mathrm{v}){ }^{33}$

What criteria is de' Mori using? First of all, he is moving towards standard Florentine Trecento usage, to the extent that he can recognize that standard in spelling, grammar, morphology; and when there is oscillation in the Trecento models, such as the contraction of future stems, he probably conforms to contemporary usage. At the same time he is moving away from archaic or obsolete Trecento words and constructions, in favor of other Trecento words that are still in use. Another factor at work seems to be the hypercorrection of words perceived as too close to regional usage, or at least the desire to differentiate written from spoken discourse: thus the elimination of apocope, and the preference for cotanto, al quale, quale . . quale over tanto, a cui, chi ... chi. I surmise that de' Mori originally learned Florentine mainly from reading, especially Boccaccio and Petrarca; that consequently he understood grammatical rules imperfectly (such as the use of esso, the article gli, etc.); and that he also picked up many words and phrases in his reading that he did not realize were no longer used. In the course of his studies and consultations between 1575 and 1590 he would have seen his "errors."

One cannot help thinking that if de' Mori had lived longer, he would have revised the Giuoco yet again. It would be more than twenty years, however, before the Vocabolario degli Accademici della Crusca (1612) would provide a reference, albeit a problematic one, for writers in Ascanio's situation. If we take the Vocabolario as the standard, whereas most of de' Mori's changes are from "wrong" to "right," some are from "right" to "wrong," some are from "wrong" to "wrong;" and many are from "right" to "right," not only in cases of obsolescence, but also in others where it is unclear why he bothered making a change at all. ${ }^{34} \mathrm{He}$ must have had a reason: clearly it was a question of style.

Style is the key to Ascanio de' Mori's ideas on language. When I first came across the passages in the Giuoco Piacevole that I have presented, a cursory reading left me with the impression that de' Mori was reluctant to accept the Trecento Florentine model. In many respects, however, he embraced Bembo's proposal - he was happy to have a standard for spelling, grammar, morphology, lexicon. His reservations, and in this he was surely not alone, had to do with style. Bembo and Della Casa imitated not only Boccaccio's language but also his style. This is what the "scrupolosi" wanted, this is what "toscaneggiare" meant, and this is what Ascanio de' Mori was not prepared to do. 


\section{NOTES}

1 There is a vast bibliography on the "questione della lingua." See Pozzi, Discussioni 25-29.

$2 \mathrm{Sec}$, for instance, Paolo Beni on oscillations in Boceaccio: "Avertiro bene che le tante e tante voci le quali quasi incerte et erranti, vengono in molie maniere dal Boccaccio usate, c senza che si possa ritrarre agevolmente qual meriti maggior lode, son in gran parte nate dall'ignoranza del volgo: tra le quale voci nel Boccaccio può annoverarsi . . . ubbidire ę obbedire, o pur ubidire et obedire: ufficio et officio, o pur oficio et uficio, o, se ci piace, ufizio ... (Parte 1, 15)

3 For more detailed accounts of de' Mori's life and for bibliography, see Sanjust, and the two contributions by Faccioli.

4 The uncertainty is due to the fact that, aside from what de' Mori himself writes in his letters and prefaces, biographical data comes from passages in his novelle that have been presumed to be autobiographical. Both Faccioli and Sanjust skip directly from Ascanio's stormy school days in the years around 1550 to his service of Emperor Maximilian and Orazio Gonzaga documented around 1570 , without commenting on the twenty-year gap.

5 See for instance Porcelli 204-5. In the thousand-page proceedings of the recent Caprarola conference on "La novella italiana" (Roma: Salerno, 1989), however, de' Mori’s Novelle are virtually ignored, meriting only a flecting reference to their publication history (263).

6 Ascanio Pipino de Mori da Ceno, Giuoco Piacevole, Mantova: Giacomo Ruffinello, 1575; Ascanio de Mori da Ceno, Giuoco Piacevolc, ristampato più corretto, \& migliorato da lui, Mantova: Giacomo Ruffinello, 1580; Ascanio de' Mori da Ceno, Giuoco Piacevole, stampato la terza volta più corretto, \& migliorato da lui, Mantova: Francesco Osanna, 1590. There is now a modern edition, ed. M. G. Sanjust, Roma: Bulzoni, 1988.

7 This was a well-known game. Girolamo Bargagli, who deseribes it under the names "giuoco dell 'ostcria" or "giuoco delle lettere" in his Dialogo de' ginochi che nelle vegghic sanesi si usano di fare of 1572 , lists it as an example of a traditional game, not as one of the new type supposedly invented by the Intronati (64).

8 Among its surprises are descriptions of ideal beauty, perfect ugliness, many different pleasure gardens, storms at sea; an encomium to the Gonzaga family; references to several now lost or unknown paintings by Mantegna, Titian, and Lorenzo Costa il Giovane; and an ode to virginity in the form of a cronaca nera tale of rape and revenge.

9 Faccioli discusses de' Mori's linguistic attitudes in the Giuoco in Mantosa. Le Lettere 2: $522-4$.

10 Strangely enough the name of the hostess changes from the first edition (Barbara Calina) to the second and third (Bcatrice Gambara). See J. Shiff, "Titian's Helle and Ascanio de' Mori," 1990 (unpublished).

11 The word "scrupolosi" may remind the reader of Castiglione's Corlegiano $(1,37)$ where it is used in a nearly identical context. There too the "scrupolosi" have an intimidating effect, such that intelligent and cultured people hesitate to speak for fear they might commit some fault of language: "Ma oggidi son certi scrupolosi, i quali, quasi con una religion c misterii ineffabili di questa lor lingua toscana, spaventano di modo chi gli ascolta, che inducono ancor molti omini nobili $\mathrm{c}$ litterati in tanta timidità, che non osano aprir bocca e confessano di non saper parlar quella lingua, che hanno imparato dalle nutrici insino nelle fasce" (150).

12 This is the whole passage in question: ". . . quando ho detto, ch'ogni una dovesse proponere il suo parere, non m'è venuto pensato d'altro, che di volere, ch'imitassimo ancora noi i nostri maggiori, per non essere sole, che incominciassimo a discordarci da loro nel modo de ${ }^{\text {" }}$ trattenimenti, ch'in simili occasioni si sogliono proponere. Signora, disse il Conte; mentre si pensano diversi partiti, nessuno se ne piglia: Non andate cosi timidamente, ma procedete alla sicura. Sgombrisi quell'oscura, \& folta nebbia, soggiunse il Cavalicre; di quel superstitioso pensiero da voi Signora, né vi curate di scguir più una via, ch'un'altra, né d'osservare tante leggi fuor di proposito. Quello, ch'il vostro giudicio vi detta, \& porge così all'improviso, 
\& quello accettate senza attendere, che di noi alcuno s'allunghi a proponere il suo parere; percioché mai non ne venircmmo a capo; in ogni modo questo nostro ragionamento non è per vedere la luce di dimane, non che per passare le severe censure di quei troppo scrupolosi, che vogliono Periodi alti, \& pieni; Colori, Metafore, \& Digressioni; dottrina, gravità; \& parole Toscane scelte, non pur ne' ragionamenti gravi, ma ne' leggieri, \& ne' burlevoli; i quali, non so vedere, in che s'offendano, s'altri vuole scrivere, dire, o farc a modo suo, mentre non noccia, o punga altrui. Haverò io dunque da non iscrivere mai, per essere Lombardo, \& per non havere l'Idioma Toscano? Porrommi in perpetuo silentio, per essere idiota? Et istarommi con le mani a cintola, per non sapere altamente negotiare? Scriverò, dirò, \& opererò a modo mio, mentre mi sarà lecito sempre, quasi ch'io non dissi malgrado loro. Iddio m'ha data lingua Lombarda, \& ispedita; intelletto semplice, \& retto; \& persona non cagionevole, ma sana, \& aitante: però della lingua voglio servirmi, \& alla Lombarda; né voglio mutarla nella Toscana; perché non tengo la Lombarda (con modestia parlando) inferiore alla Toscana, laquale pur si scrve delle parole di lombardia, \& d'altri luoghi. Voglio usar l'intelletto, \& con quella santa, cotanto alla Maestà divina, accetta simplicità: \& della vita voglio servirmi in ogni lodato essercitio, per quanto valc: \& dica poi, chi vuole, contra me. Tengo questo mio saldo proponimento così impresso nel cuore, che non è per rimoversene mai. Certamente, disse la Signora Bcatrice, quando vien fatta, detta, o scritta per alcuno qualche cosa per Giuoco, \& per fuggir l'otio cagione di tanti mali, senza toccare altrui, è brutta cosa morder quel tale, che l'ha fatta, detta, o scritta: perche sì come ogni uno può distribuire l'attioni sue (mentre non siano inique, \& malvagie) a piacer suo, così non può altri essere astretto a vederle, udirle, o leggerle contra sua voglia" (1590 ed., 6v-7r).

13 "Insomma parmi di essermi accorto, che, dove ha potuto faticarsi per giovare, non si sia sparmiato; sì che né $\mathrm{V}$. $\mathrm{S}$. che è giudiciosa, \& gli è amorevole amico; né alcuno simile a lei, né pcr aventura altri, che non porti nome di crudele, debba, o possa ragionevolmente riprenderlo, né biasimarlo; ma più tosto lodarlo ... " (165).

14 "Parmi . . . che nella lingua non si sia lontanato punto da migliori auttori e, se ad alcuno di loro meno severo si è accostato in alcune voci, quantunque nuove, si sia nondimeno sforzato di eleggere le più dolci, le più sonore, le più belle, le più eleganti, le più intelligibili e le più significanti, come sicuro che debbano per la loro docilità, col favore degli scrittori moderni amorevoli e intendenti, domesticarsi ancora in maniera che vengano accettate per nostre, dove ora sono a pena conosciute, e ben da pochi, per istraniere; che intorno alla ortografia egli non abbia parimente traviato da' loro precetti."

15 The whole passage reads as follows: "Quantunque sia mai scmpre suto mio principale oggetto il gir sovente armeggiando, \& vagando hor quinci, hor quindi, per valli ombrosc, \& per monti alpestri, a cagione di meritarmi qualche segnalato honore; nulladimeno non mi si è mai scordato in tutto il castigato favellare, ch'appresi (non ha guari) nella mia tencra giovanezza, non tralasciando ctiandio to studio delle belle volgari lettere per diletto, \& per non mescolarmi colla bassezza della sciocca plebe, \& per eternarc il mio nome per questa via, malgrado della edace germana di Morfeo. 11 che pcraventura testé m'anderà vendicando con qualche mia sodisfattione appo voi non poca fama di ben terso favellatore, avegnadio, ch'io la reputi leggiera a petto della molta gloria, ch'altronde attendo per vie più certo, sicuro, \& più honorato calle; Se Martc, \& Bellona (il cui favore unqua non mi venne meno) di presente fatti invidiosi, \& emuli alla mia grandezza, non mi congiurano contra, \& non mi contrariano, \& perversano; Cosa che non paventerebbe però punto l'intrepido, \& saldo mio cuore; percioché a lor'onta col proprio natio valore, \& co' propri vanni m'estollerei, dove m'invita a sormontare l'immortale occhiuta Dea. Gnaffe, chenti si siano questi miei non inusi discorsi, suggeriti, da cui può fomentare i rimprocchi, \& imbolare la boce, \& fedire chiunque; tali ve li berretc Mone mie formosc, \& dolci; \& voi Babbi miei mclensi rimbambiti. Non è questo un principio alto, \& degno dell'aspettatione c'havevate di me? Anzi dignissimo, disse la Signora Isabella, Toscano nostro gentilissimo da Brescia: II che mossc riso in tutti; Ma la Signora Beatrice, tosto, dissc, che vi vidi aprire la bocca, mi cadé in mente, \& giudicai, che 
doveste a punto, a punto uscirne con un tale principio. O poteva, soggiunse egli, di meno? A vostro honore, che niuno di voi fin'a quest'hora ha saputo ornare il suo ragionamento pur d'una sola di coteste eleganti parole, come ho fatto io di cotante (mercé della vostra ritentiva) \& sete pur Boccacieschi tutti. Credete voi, che si gittasse il danaio, quando mi s'imparava di toscaneggiare? per lo che di nuovo si diede nelle risa. Ma il Conte disse, non vi fate però beffe di quelle parole; che dopo il gran Maestro Boccaccio, il Bembo, il Casa, il Molza, il Guidiccione, \& altri famosi scrittori, \& degni d'essere imitati da noi, le hanno approbate, $\&$ n'hanno d'alcune sparsi, come di preciose gemme, i loro dotti scritti. Cotesto non faccio io, soggiunse egli; ma m'è montato così un humore, per farvi uscire a dire qualche cosa, \& quello apunto, c'havete detto. Il Signor Tranquillo, disse il Cavaliere, con quel suo motto ha voluto leggiadramente accennarne, che posto che siano quelle parole belle, buone, degne, preciose, \& istimate da que' grand'huomini, non però soneriano altrimenti in bocca di noi in un breve nostro ragionamento, di quello, che s'habbiano peraventura sonato in quella di lui, che l'ha dette per ischerzo: che se essi l'usarono, \& di rado, \& ne' volumi, \& a luogo, \& a tempo le usarono, spargendovele per entro opportunamente con meraviglioso artificio, quasi per sollevare, \& per ricreare il lettore. Egli è, come dite, soggiunse il Sig. Tranquillo; Poi ripigliato il suo primo dire, seguì . A questo proposito d'apprender lettere Tosche . . ." (1590 ed., 18v-19v).

16 Migliorini 376. Some of these words were frequent targets of scorn. Guari was often held up as an example of archaic Tuscan, ridiculed by Equicola and Lenzoni (Pozzi, Discussioni 50, 379), Citolini and Tassoni (Migliorini 376, 412). Testé was considered too exclusively Florentine by Citolini and Tassoni (Migliorini 376, 412); by Varchi, citing Vellutello (Pozzi, Discussioni 582), and Trissino, who put suto in the same category (Pozzi, Discussioni 134, Migliorini 316). Among the many forms Beni cited as evidence that the modern language was superior to that of Boccaccio were suto and fedire (Parte 1,7-8). Valeriano considered melensaggine and gnaffe specifically Florentine (Pozzi, Discussioni 87); and he and Aretino both poked fun at sovente and chente as archaisms (Pozzi, Discussioni 50; Migliorini 375); Aretino added quinci and quindi. In his Anticrusca of 1612, Beni says of chenti "che troppo affettato anzi da ridere fora stimato hora un tal parlare" (Parte 1, 20). By then, in fact, even some members of the Accademia della Crusca deemed chente too dead to use (Migliorini 436-37). On the other hand Gelli used chente (Opere 473), but did consider buona pezza and la bisogna archaic (Opere 475; Migliorini 375). And to confuse matters more, though Beni mocks chente, he himself uses buona pezza and etiandio (e. g., Parte 4, 211).

17 Paolo Beni admires Bembo's verse and considers him too learned to imitate Boccaccio's worst faults, but condemns his prose style as "Boccacesco" rather than "dolce, temperato e gentile." Among its defects, he says, is the frequent use of words like chenti, guari, and quantunque, among others (Parte 1, 117-18).

18 This position can be seen in Gelli (Capricci del Bottaio V). Words used sparingly by Boccaccio are overused and misused by his imitators: "Piglieranno alcune parole usate qualche volta dal Boccaccio o dal Petrarca, ben che di rado, le quali quanto manco le trovano usate da essi, tanto paiono lor più belle: come sarebbono guari, altresi, sovente, adagiare, soverchio, e simili; e perché e' non hanno per natura né il vero significato, né il vero suono nell'orecchio, le pongon quasi in ogni luogo, e bene spesso fuor di proposito: e così le vengono a torre la sua bellezza naturale." (Pozzi, Trattatisti 965). See also Speroni’s comment on Petrarch's archaisms (uopo, unquanco, sovente), which shine like stars on a clear night (Pozzi, Trattatisti 664).

$19 \mathrm{He}$ would have liked to "satollar[si] di essa preciosissima Crusca gli occhi, le orecchie, l'odorato, il gusto e tutto il rimanente di [se] stesso" (Lettere 147, quoted in Sanjust 78).

20 When Tasso arrived at the Mantuan court in 1586, de' Mori sent him a copy of the Giuoco Piacevole. They later met and de' Mori helped Tasso obtain the books he needed for his various projects (such as a copy of Olaus Magnus for work on Torrismondo). De' Mori did send him the manuscript of his Lettere, asking him to put it "sotto la sua finissima 
lima" before he sent it to the printers. Tasso suggested a very few changes and returned it with his praise. At another time he wrote three sonnets on the death of one of de' Mori's sons (see Sanjust 73-4; Solerti 1, 502-04). A perusal of the "spoglio linguistico" in Ezio Raimondi's edition of the Dialoghi shows that Tasso's own linguistic usage was subject to so many oscillations that it would be difficult to imagine him advising a colleague on these matters. Tasso is consistent, however, in the use of inticro and intieramente (Dialoghi 1, 212), whereas de' Mori ultimately rejects these forms in the last edition of the Giuoco (28v).

21 The most common alterations in spelling have to do with: single or double consonants (mamella / mammella, rubbare / rubarc); diphthongization of tonic vowels (altera / alticra, intiera / intera); oscillations among ci / ti / z (datio / dacio, stuccicando / stuzzicando), between e / $i$ (Prencipe / Principe, gittare / gettare), and between o / $u$ (congiunto / congionto, ridiculosa / ridicolosa); and lenition of intervocalic consonants (servitore / senvidore, loco / luogo).

22 See, for instance, Claudio Tolomei in Il Cesano: "Non mi sdimenticarò già che appresso de' Toscani ancora certi pronomi del caso dritto al piegato si mutano, dicendosi . . essi o ver eglino, di loro; esse o ver elleno, di loro" (Pozzi, Discussioni 247). And yet this could not have been a hard and fast rule if Giovan Battista Gelli, himself a Florentine, writes "da essi," "in essa" in his work entitled, appropriately enough, Ragionamento sopra le difficultà del mettere in regole la nostra lingua (Opere 462-63). Here are some examples of de' Mori's revisions: "A questo sì licto, \& sì gioioso Carnevale alcuni spiriti gentili procurarono di dare il supremo condimento, col far recitare l'ultima notte d'esso con reale apparato una nova Tragicomedia" (1575 ed., 1r); "l'ultima notte di quello" (1580 ed., 5r). “. . . dierono principio a danzare, \& per lunga pezza continuarono passeggiando, et talhora alcuna di esse framettendovi una gagliarda ... (1575 ed., 2r); "alcuna di loro" (1580 ed., 6r). "Mentre dimorai poscia in quella antica Città, ... mi pigliai per piacere d'andar vedendo quel, che di segnalato c̀ in essa" (1575 ed., 35v); “in lei” (1580 ed., 37v).

23 E. g., "il comandamento vostro, a cui intendo esser'obediente" (1575 ed., 2v); "alquale" (1580 ed., 6v). "II Giuoco, di cui parlo, è di questa maniera" (1575 ed., 3v); "delquale favello" (1580 ed., 7v). "Ne parve scorgere una Vecchiarella, a cui tosto ci riducevamo" (1575 ed., 10r); "allaquale" (1580 ed., 13v). "Mi pareva che se ne facesse incontra un huomo di matura ctà, a cui . . . venivamo raccomandate strettamente” (1575 ed., 10r); "alquale" (1580 ed., 13v).

24 Boccaccio and Petrarca use both chi ... chi and quale . . quale. Altri . . altri, however, while it occurs in the Canzoniere, is not found once in the Decameron. Other examples are: "tutti si posero a pensare altri una cosa, et altri un'altra" (1575 ed., 5v); "quale . . quale" (1580 cd., 9v). "Solamente . . . attendevano alla propria salute, apparecchiandosi a gara di porsi altri supra una tavola, altri sopra un legno, altri sopra il picciolo schifo, \& altri sopra altre sorti d'istromenti" (1575 ed., 26r); "quale . . quale . . quale . . quale" (1580 ed., 28v).

25 See Giambullari 193: "Et advertiscasi nelle copulative, che anco c̀ propria del verso; anche della prosa." Paolo Benj objects strenuously: "Perché usar ancora et anche, rifiutando anco voce senza dubbio più sonora e dolce di anche et insieme più regolata, per nascere da ancora ch'è la perfctta? che però a me giova con buona gratia del Boccaccio usarla ben volentieri: e seguir oltr'il Petrarca, che a me val per mille, qualch'altro antico e moderno Prosatorc. Poscia che il voler in somma che si riservi al verso, non è altro che addurre la nostra lingua ad angustic maggiori senza cagion'alcuna, e, quel ch'è peggio, mostrar di haver poco giuditiosa orecchia. Certamente il Petrarca fece di quest'anche sì poca stima, che apena volle fra mille anco una o due volte riceverla. (Parte 1, 13)

26 E.g., “. . . sapevale male, che dovessero partire indi tanto rammaricate" (1575 ed., 1v); "cotanto" (1580 ed., 5v). “. . . quella santa, tanto a sua Maestà divina, accetta simplicità “ (1575 ed., 3r); “cotanto” (1580 ed., 7r). “. . reggereste maggior peso, avenga che vi mostriate hora tanto debile (1575 ed., 4v); “cotanto" (1580 ed., 9r). 
27 Also gastigo (1580 ed., 35v) / castigamento (1590 ed., 35r), but never, strangely enough, castigo / castigamento or gastigo / gastigamento. Beni, however, says of gastigamento, "hora veramente riuscirebbe da ridere" (Parte 1, 9-10); and he sees no reason to "sprezzar e fuggir obligo ... e dir obbligazione" (Parte 1, 12).

28 "Noi poscia senza dir altro dopo conveniente pezza ci partimmo (1575 ed., 29v); "dopo conveniente spatio ci dipartimmo" (1580 ed., 31v).

29 E.g., "me n'andai alla loggia per ispedire alcune mie bisogne" (1580 ed., 9v); "alcuni miei bisogni” (1590 ed., 9v). “. . . occorrendogli per alcure sue bisogne passare a Bologna di Mare" (1580 ed., 15v); "alcuni suoi bisogni” (1590 ed., 15v). “. . . essendo in briga un mio fratello cugino giovanetto molto con certo soldato ... che il villaneggiava molto, la bisogna caminò di modo, ch'egli ... gli trasse il farnetico di capo" (1580 ed., 38v-39r); "il fatto caminò “ (1590 ed., 39r).

30 “. . . il custode del Giardino" (1580 ed., 18r) becomes "chi guardava il Giardino" (1590 ed., 18r). The Vocabolario della Crusca lists custodio and adds "oggi custode."

31 The Vocabolario della Crusca does not list tartaruga.

32 Other examples are: "de' stranieri," “de' schiavi” (1580 ed., 20r) / "de gli stranieri," "de gli schiavi” (1590 ed., 20r); “de' sciocchi” (1580 ed., 46v) / "de gli sciocchi” (1590 ed., 46v).

33 This change is so prevalent and so striking that it would merit further investigation: why did he use the construction so very often in the earlier editions, and what drove him to change it for the final one? Here are some more examples: "Venne lodata sommamente il gentil Enimma, dopo che s'intese la vera spositione; \& venne confermato il giudicio, che se ne fece alla prima" (1580 ed., 10v); "fu lodato . . . fu confermato" (1590 ed., 10v). "Quel che vien negato all'acutezza del mio sottil'ingegno, difficilmente verrà concesso alla grossezza dell'ingegno di questi altri Signori” (1580 ed., 28r); "è negato . . . sarà concesso" (1590 ed., $28 \mathrm{r}$ ). "Quel c'ho detto per risposta alla Signora Beatrice, tutto $m$ 'è venuto favellato solamente per accennarle, che . . " (1580 ed., 11r); "ho favellato" (1590 ed., 11r). “. . . il che non n'era venuto scorto prima" (1580 ed, 16r); "non havevamo veduto" (1590 ed., 16r). "ll che ... ne poteva parer facilmente sogno, quando il custode del Giardino non n'havesse resi certi ciò essere tanto in essenza, quanto n'era v'enuto mirato in apparenza" (1580 ed., 18r); "havevamo veduto" (1590 ed., 18r).

34 Examples of changes from words or forms which will not be recognized by the Crusca to ones that will: hospite / hoste (Crusca oste), allegria / allegrezza, castigo / gastigamento, tartaruga / testuggine, servitore / servidore. Changes from words or forms that will be recognized by the Crusca to ones that will not: funi / gomene, forse / forsi, commodo / commodità (Crusca comodo), omai / ormai (Crusca omai, oramai), infermità / infirmità, maraviglioso / meraviglioso, autore / auttore. Changes between two forms, neither of which the Crusca will consider correct: mestiero / mestieri and mestieri / mestiero (Crusca mestiere); remutiare, rinontiare / rinonciare (Crusca rinunziare). Changes between two words or forms, both of which the Crusca will consider correct: spesso / sovente, parere / aviso (Crusca avviso), cessare di / lasciare di, secondo / conforme a, altramente / altrimenti.

\section{WORKS CITED}

Bargagli, Girolamo. Dialogo de' giuochi che nelle vegghie sanesi si usano di fare. Ed. Patrizia D'Incalci Ermini. Siena: Accademia Senese degli Intronati, 1982.

Battaglin, Deanna. "Il linguaggio tragicomico del Guarini e l'elaborazione del Pastor fido." Lingua e strutture del teatro italiano del Rinascimento. Padova: Liviana, 1970. 293-353.

"Salviati e le 'Osservazioni al Pastor fido' del Guarini." Atti e Memorie della Accademia Patavina di Scienze Lettere ed Arti, Memorie della Classe di Scienze Morali, Lettere ed Arti 77 (1964-65): 249-84.

Beni, Paolo. L'Anticrusca. [Parte prima]. Padova, 1612. Rpt. Firenze: Accademia della Crusca, 1983. 
L'Anticrusca. Parte II, III, IV. Ed. Gino Casagrande. Firenze: Accademia della

Crusca, 1982.

Castiglione, Baldesar. Il libro del cortegiano. Ed. Bruno Maier. 2nd ed. Torino: UTET, 1964.

Faccioli, Emilio. “Ascanio de' Mori." Mantova. Le Lettere. 3 vols. Mantova: Istituto Carlo d'Arco, 1962. 2: 501-52.

"La vita e gli scritti di Ascanio de' Mori." Bollettino storico mantovano 5-6

(1957): 67-83.

Gelli, Giovan Battista. Opere. Ed. Delmo Maestri. Torino: Utet, 1976.

Giambullari, Pierfrancesco. Regole della lingua fiorentina. Ed. Ilaria Bonomi. Firenze: Accademia della Crusca, 1986.

Migliorini, Bruno. Storia della lingua italiana. 2 vols. Firenze: Sansoni, 1988.

Mori, Ascanio de'. Giuoco Piacevole. 1st ed. Mantova, 1575. 2nd ed. Mantova, 1580. 3rd ed. Mantova, 1590. . Lettere. Mantova, 1590.

Porcelli, Bruno. "La novella e la narrativa." Letteratura italiana. Storia e testi. 4 II. Il

Cinquecento. Dal Rinascimento alla Controriforma. Bari: Laterza, 1974. 119-223.

Pozzi, Mario, ed. Discussioni linguistiche del Cinquecento. Torino: Utet, 1988. ed. Trattatisti del Cinquecento. Tomo 1. Milano-Napoli: Ricciardi, 1978.

Sanjust, Maria Giovanna. "Ascanio de' Mori da Ceno: il miraggio della corte mantovana." Italianistica 16 (1987): 51-79.

Solerti, Angelo. Vita di Torquato Tasso. 3 vols. Torino: Loescher, 1895.

Tasso, Torquato. Dialoghi. Ed. Ezio Raimondi. 3 vols. Firenze: Sansoni, 1958.

Vocabolario degli Accademici della Crusca. Venezia, 1612. Rpt. Firenze: Licosa, 1974. 